\title{
THE INFLUENCE OF WORK DICIPLINE AND WORK ENVIRONMENT ON ORGANIZATIONAL COMMITMENT EMPLOYEE OF SBU ENERGY AT PT BIRO KLASIFIKASI INDONESIA (PERSERO) NORTH JAKARTA
}

\author{
Dewi Susita \\ Fakultas Ekonomi Universitas Negeri Jakarta \\ Email: dewisusita@yahoo.com \\ Wahiddah Muslimah \\ Fakultas Ekonomi Universitas Negeri Jakarta \\ Email: wahiddahmuslimah@gmail.com \\ Agung AWS Waspodo \\ Fakultas Ekonomi Universitas Negeri Jakarta \\ Email: awaspodo@gmail.com
}

\begin{abstract}
The purpose of this research are: 1) To know the description for the work dicipline, work environment and organizational commitment employee of SBU Energy at PT Biro Klasifikasi Indonesia (Persero) North Jakarta, 2) To know the influence work dicipline on organizational commitment employee of SBU Energy at PT Biro Klasifikasi Indonesia (Persero) North Jakarta, 3) To know the influence work environment on organizational commitment employee of SBU Energy at PT Biro Klasifikasi Indonesia (Persero) North Jakarta, 4) To know the influence work dicipline and work environment on organizatonal commitment employee of SBU Energy at PT Biro Klasifikasi Indonesia (Persero) North Jakarta. This research is taken 70 emplooyee of SBU Energy at PT Biro Klasifikasi Indonesia (Persero) North Jakarta, Jakarta. The technique of data collection used method by distributing questionnaires, which then processed with program SPSS version 21.0. this research using descriptive analysis and explanatory. The result of regression shows that there is positive and significant influence work dicipline on organizational commitment, there are positive and significant influence work environment on organizational commitment.
\end{abstract}

Keywords: Work Dicipline, Work Environment, Organizational Commitment. 


\section{PENDAHULUAN}

Dalam mewujudkan sumber daya manusia yang berkualitas, perusahaan perlu menciptakan diantaranya lingkungan kerja yang kondusif, semangat kerja dan disiplin kerja, imbalan yang layak dan adil, sikap dan etika dari atasan untuk membentuk perilaku kerja karyawan dengan baik sehingga memotivasi karyawan untuk ikut terlibat dalam memajukan perusahaan melalui komitmen organisasi.

Komitmen organisasi pada diri setiap karyawan akan tinggi jika mereka merasa puas dan mampu memenuhi semua kebutuhan hidup sesuai dengan apa yang diharapkan. Akan tetapi, karyawan yang tidak terpenuhi kebutuhannya akan merasa tidak puas dan cenderung dapat memicu ketidakhadiran, rendahnya kinerja, tingginya turnover, dan pindah pekerjaan.Adapun kondisi tersebut juga dialami pada perusahaan yang bergerak dibidang pengklasifikasian kapal berdasarkan konstruksi pembangunan dan pemeliharaan mesin dan listrik kapal niaga berbendera Indonesia dan kapal berbendera asing yang secara reguler beroperasi di perairan Indonesia.

PT Biro Klasifikasi Indonesia (Persero) Jakarta Utara merupakan perusahaan yang mengawali bisnisnya pada tanggal 1 Juli 1964 di Jakarta oleh Menteri Perhubungan Laut.Salah satu tujuan perusahaan yaitu memberikan penilaian atas baik atau tidaknya kapal tersebut untuk berlayar. Dari hasil wawancara yang dilakukan peneliti dengan manajer divisi SDM dan umum perusahaan, peneliti dapat mengetahui indikasi rendahnya komitmen adanya kondisi ketidakhadiran dan turnover karyawan bagian SBU Energi PT Biro Klasifikasi Indonesia (Persero) selama tahun 2016.Berikut ini adalah data alpha karyawan dan data keterlambatan karyawan PT Biro Klasifikasi Indonesia (Persero) pada bagian SBU Energi.

Tabel 1.Data Alpha (Tidak Hadir Tanpa Keterangan) Karyawan Bagian SBU Energi PT Biro Klasifikasi Indonesia (Persero)

\begin{tabular}{cccc}
\hline Bulan & Total Karyawan & $\begin{array}{c}\text { Total Alpha } \\
\text { Karyawan }\end{array}$ & Persentase \\
\hline Juni & 115 & 15 & $13,0 \%$ \\
\hline Juli & 85 & 13 & $15,3 \%$
\end{tabular}




\begin{tabular}{cccc}
\hline Agustus & 85 & 11 & $12,9 \%$ \\
\hline September & 85 & 8 & $9,4 \%$ \\
\hline Oktober & 85 & 8 & $9,4 \%$ \\
\hline November & 85 & 8 & $9,4 \%$ \\
\hline Desember & 85 & 10 & $11,8 \%$
\end{tabular}

Sumber : Data diolah oleh Peneliti, 2016

Berdasarkan Tabel 1. menunjukkan jumlah karyawan yang terlambat pada tahun 2016 dinyatakan dalam bentuk presentase. Dari data alpha dan data keterlambatan karyawan PT Biro Klasifikasi Indonesia (Persero) Bagian SBU Energi dapat diketahui bahwa pada bulan Juni 2016 - Juli 2016 memilki jumlah tingkat alpha tertinggi yaitu sebesar (15,3\% dan 13,0\%) kemudian mulai menurun pada bulan Agustus 2016 (13,4\%) dan kembali meningkat hingga bulan Desember (11,8\%). Sedangkan pada data keterlambatan PT Biro Klasifikasi Indonesia (Persero) mengalami naik turun (tidak stabil) dimulai dari bulan Juni 2016 sampai Desember 2016, tingkat keterlambatan dapat dikatakan tinggi karena dalam periode 7 bulan terakhir (Juni 2016 - Desember 2016) persentase keterlambatan selalu menunjukkan angka keterlambatan selalu menunjukkan angka keterlambatan angka keterlambatan melebihi $15 \%$. Hal tersebut menjadi indikasi bahwa adanya tingkat disiplin kerja dalam diri karyawan PT Biro Klasifikasi Indonesia (Persero) Bagian SBU Energi dikatakan cukup rendah dimana seharusnya jumlah alpha dan keterlambatan kerja berada pada nilai 0 (nol).

Selanjutnya peneliti memperoleh data kedua berupa data turnover karyawan bagian SBU Energi PT Biro Klasifikasi Indonesia (Persero) selama periode 2014 sampai 2016 dapat dilihat pada tabel 2 dibawah ini:

Tabel 2.Data Turnover Karyawan Bagian SBU Energi PT Biro Klasifikasi Indonesia (Persero)2014 - 2016

\begin{tabular}{lccc}
\hline \multicolumn{1}{c}{ Tahun } & 2014 & 2015 & 2016 \\
\hline Karyawan Keluar & 7 & 11 & 20 \\
\hline Karyawan Masuk & 9 & 13 & 10 \\
\hline Jumlah Karyawan & 68 & 77 & 115 \\
\hline Persentase & $10,2 \%$ & $14,2 \%$ & $17,4 \%$
\end{tabular}

Sumber: Data diolah oleh peneliti, 2017 
Berdasarkan data di atas, dapat diketahui terjadinya kecenderungan kenaikan tingkat turnover karyawan selama periode 2014 sampai 2016.Selama tahun 2014 presentaseturnoversebesar 10,2\% pada tahun 2015 sebesar 14,2\% dan pada tahun 2016 sebesar 17,4\%. Hal ini menunjukkan terjadinya kecenderungan kenaikan tingkat kehadiran dan turnover sehingga memperkuat rendahnya komitmen organisasi pada karyawan PT Biro Klasifikasi Indonesia (Persero) Bagian SBU Energi.Hal ini menunjukkan rendahnya komitmen organisasi dapat terlihat dari terabaikannya nilai-nilai kedisiplinan pada perusahaan.

Selain disiplin kerja, faktor kedua yaitu lingkungan kerja yang mempengaruhi rendahnya komitmen organisasi.Lingkungan kerja dalam suatu perusahaan mempunyai pengaruh langsung terhadap komitmen karyawan yang bekerja pada perusahaan tersebut.Adapun, permasalahan lingkungan kerja fisik bagian SBU Energi PT Biro Klasifikasi Indonesia (Persero) terlihat pada sempitnya tata ruang kerja dan tata letak kerja yang kurang nyaman, dimana jarak antara karyawan satu dengan yang lainnya berdekatan sehingga ruang gerak sulit.

Selain itu, dari segi aspek kebisingan dapat disebabkan karena suara mesin pada gedung sedang dalam tahap pembangunan, sehingga menimbulkan suara berisik membuat karyawan sulit berkonsentrasi.Dari segi fasilitas untuk beristirahat, dan ruang ibadah kurang memadai.Selain itu, kualitas udara juga tidak sehat disebabkan banyak debu dan polusi dari kegiatan pembangunan serta pertukaran udaranya kurang baik karena karyawan merasakan kepengapan dengan kondisi AC dan kipas angin yang sering rusak.

Sedangkan dari segi lingkungan non fisik yaitu hubungan komunikasi antara sesama karyawan bagian SBU Energi terjadinya kerjasama yang kurang baik dalam hal pembagian tugas kerja yang seringkali dilimpahkan kepada beberapa orang karyawan saja yang dianggap sudah lebih lama bekerja di perusahaan tersebut.Kemudian, terdapat masalah hubungan antara pimpinan atau atasan dengan karyawan kurang begitu baik dalam pengambilan keputusan seringkali kurang kooperatif, serta kurang memberi memotivasi karyawan dalam pengerjaan konstruksi pembangunan dan pemeliharaan mesin kapal agar sesuai target yang diharapkan membuat karyawan tidak nyaman dan menjadi beban 
tersendiri bagi para karyawan.Hal tersebut menjadi indikasi masalah lingkungan kerja yang buruk dan mempengaruhi rendahnya komitmen organisasi pada perusahaan.

\section{Rumusan Masalah}

1. Bagaimana deskripsi disiplin kerja, lingkungan kerja, dan komitmen organisasi karyawan pada PT Biro Klasifikasi Indonesia (Persero)?

2. Apakah disiplin kerja berpengaruh terhadap komitmen organisasi karyawan bagian SBU Energi PT Biro Klasifikasi Indonesia (Persero)?

3. Apakah lingkungan kerja berpengaruh terhadap komitmen organisasi karyawan bagian SBU Energi PT Biro Klasifikasi Indonesia (Persero)?

4. Apakah disiplin kerja dan lingkungan kerja dapatmemprediksikomitmen organisasi karyawan bagian SBU Energi PT Biro Klasifikasi Indonesia (Persero)?

\section{Tujuan Penelitian}

1. Mengetahui bagaimana deskripsi disiplin kerja, lingkungan kerja, dan komitmen organisasi karyawan bagian SBU Energi PT Biro Klasifikasi Indonesia (Persero).

2. Mengetahui apakah disiplin kerja berpengaruh terhadap komitmen organisasi karyawan bagian SBU Energi PT Biro Klasifikasi Indonesia (Persero).

3. Mengetahui apakah lingkungan kerja berpengaruh terhadap komitmen organisasi karyawan bagian SBU Energi PT Biro Klasifikasi Indonesia (Persero).

4. Mengetahui apakah disiplin kerja dan lingkungan kerja dapat memprediksi kenaikan komitmen organisasi karyawan bagian SBU Energi PT Biro Klasifikasi Indonesia (Persero).

\section{KAJIAN TEORITIK \\ Komitmen Organisasi}


Komitmen Organisasi menurut Kaswan (2012:293) merupakan "Ukuran kesediaan karyawan bertahan dengan sebuah perusahaan di waktu yang akan datang”.

Pendapat lain yaitu Robbins (2008:44) menjelaskan "Komitmen Organisasi adalah keadaan dimana karyawan mengaitkan dirinya ke dalam organisasi tertentu dan sasaran serta berharap mempertahankan keanggotaan dalam organisasi itu".

Menurut Luthans (2015:188) "Komitmen Organisasi adalah suatu sikap yang mencerminkan loyalitas pekerja pada organisasi dan merupakan suatu proses yang sedang berjalan melalui mana peserta organisasi menyatakan perhatian mereka terhadap organisasi dan kelanjutan keberhasilan dan kesejahteraannya".

Dari beberapa pendapat ahli diatas, dapat disimpulkan bahwakomitmen organisasi pada dasarnya adalah sikap atau perilaku yang menunjukkan loyalitas seorang karyawan terhadap organisasinya, yang diwujudkan dengan keinginan menjadi bagian dari anggota organisasi yang meliputi adanya kepercayaan dan penerimaan terhadap tujuan-tujuan dan nilai-nilai dari suatu organisasi, serta kemauan untuk menggunakan usaha yang tinggi demi kepentingan organisasi, dan keinginan untuk tetap bertahan dengan memelihara keanggotaan dalam organisasi.

\section{Disiplin Kerja}

Disiplin juga merupakan salah satu fungsi manajemen sumber daya manusia yang penting dan merupakan kunci tercapainya tujuan perusahaan.

Menurut Rivai (2014:599) menjelaskan "Disiplin kerja adalah suatu alat yang digunakan para manajer untuk berkomunikasi dengan karyawan agar mereka bersedia untuk mengubah suatu perilaku serta sebagai suatu upaya untuk meningkatkan kesadaran dan kesediaan seseorang menaati semua peraturan perusahaan dan norma-norma sosial yang berlaku.

Pendapat serupa dikemukakan Hasibuan (2009:195) "Disiplin kerja adalah kesadaran dan kesedian seseorang menaati semua peraturan perusahaan dan norma-norma sosial yang berlaku.Ketaatan ini dapat diwujudkan dalam bentuk sikap, tingkah laku, maupun perbuatan yang sesuai dengan peraturan tersebut”. 
Kemudian menurut Singodimedjo (2011:86) "Disiplin kerja adalah sikap kesediaan dan menaati segala norma dan peraturan yang berlaku di sekitarnya. Disiplin kerja karyawan yang baik akan mempercepat tujuan perusahaan, sedangkan disiplin kerja yang merosot akan menjadi penghalang dan memperlambat pencapaian tujuan perusahaan".

Berdasarkan pengertian yang dikemukakan oleh para ahli tersebut, maka dapat disimpulkan bahwa disiplin kerja merupakan sikap kesediaan dan kesadaran yang ada di dalam diri seorang karyawan untuk memenuhi dan menaati semua peraturan dan norma yang berlaku serta sadar akan tugas dan tanggung jawabnya. Dengan kata lain, disiplin kerja dapat dijadikan sebagai pedoman perusahaan untuk mencapai tujuan perusahaan.

\section{Lingkungan Kerja}

Aspek lingkungan kerja dalam suatu organisasi merupakan salah satu hal yang penting sehingga dapat menunjang aktivitas atau pekerjaan karyawan dalam melaksanakan proses produksi.

Lingkungan kerja menurut Robbins (2009:20), “lingkungan kerja merupakan segala sesuatu yang berada di luar organisasi yang secara potensial mempengaruhi pegawai dalam bekerja dan pada akhirnya mempengaruhi kinerja organisasi”.

Pendapat serupa dikemukakan Nitisemintodalam Hafizurrachman (2009:64) menjelaskan "segala sesuatu yang ada di sekitar para pekerja dan yang dapat mempengaruhi dirinya dalam menjalankan tugas-tugas yang dibebankan".

Selain itu, menurut pendapat Sedarmayanti (2009:21)“lingkungan kerja adalah keseluruhan alat perkakas dan bahan yang dihadapi, lingkungan sekitarnya dimana seseorang bekerja, metode kerjanya, serta pengaturan kerjanya baik sebagai perseorangan maupun sebagai kelompok.

Berdasarkan pengertian yang dikemukakan oleh para ahli tersebut, dapat disimpulkan bahwa lingkungan kerja merupakan keadaan tempat kerja seseorang karyawan yang meliputi lingkungan fisik maupun lingkungan non fisik yang mempengaruhi pekerja dalam menjalankan berbagai tugasnya. Namun bila 
lingkungan kerja dan suasana kerja yang baik akan menciptakan lingkungan dalam organisasi tersebut tersusun secara baik, begitu juga sebaliknya.

\section{Model Penelitian}

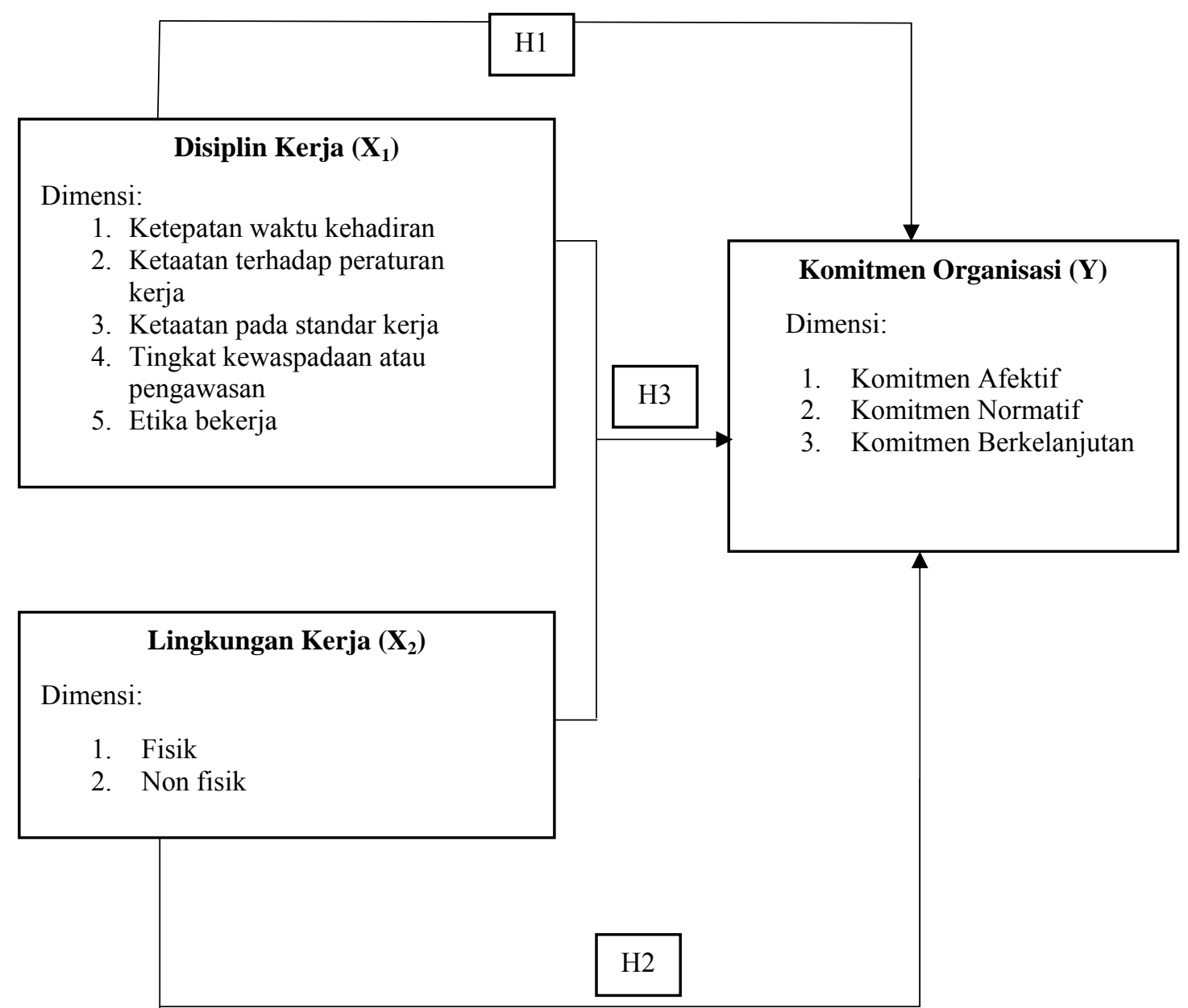

Sumber : Diolah oleh peneliti, 2017

Gambar 2. Model Penelitian

\section{Hipotesis}

Berdasarkan kajian teori dan model penelitian di atas , maka hipotesis pada penelitian ini adalah:

Hipotesis 1 
Ho : Disiplin kerja tidak berpengaruh terhadap komitmen organisasi pada karyawan PT Biro Klasifikasi Indonesia (Persero) Bagian SBU Energi.

Ha : Disiplin kerja berpengaruh terhadap komitmen organisasi pada karyawan PTBiro Klasifikasi Indonesia (Persero) Bagian SBU Energi.

Hipotesis 2

Ho : Lingkungan kerja tidak berpengaruh terhadap komitmen organisasi pada karyawan PTBiro Klasifikasi Indonesia (Persero) Bagian SBU Energi.

Ha : Lingkungan kerja berpengaruh terhadap komitmen organisasi pada PTBiro Klasifikasi Indonesia (Persero) Bagian SBU Energi.

Hipotesis 3

Ho : Disiplin kerja dan lingkungan kerja tidak dapat memprediksi kenaikankomitmen organisasi pada karyawan PT Biro Klasifikasi Indonesia (Persero) Bagian SBU Energi.

Ha : Disiplin kerja dan lingkungan kerja dapat memprediksi kenaikan komitmen organisasi pada karyawan PTBiro Klasifikasi Indonesia (Persero) Bagian SBU Energi.

\section{METODE PENELITIAN}

Metode yang digunakan dalam penelitian ini adalah metode deskriptif dan metode eksplanatori (explanatory research).Penelitian deskriptif menurut Sanusi(2011:13) merupakan penelitian yang disusun dalam rangka memberikan gambaran secara sistematis tentang informasi ilmiah yang berasal daruntuk mengumpulkan informasi mengenai status suatu gejala yi subjek atau objek penelitian".Dengan menggunakan penelitian deskriptif, peneliti mencoba mendeskripsikan dan mengetahui gambaran pemasalahan-permasalahan yang ada di PT Biro Klasifikasi Indonesia (Persero) Bagian SBU Energi.Sedangkan penelitian eksplanatori (explanatory research) merupakan penelitian yang membuktikan adanya sebab akibat dan hubungan yang mempengaruhi atau dipengaruhi dari dua atau lebih variabel yang diteliti. 
Populasi pada penelitian ini adalah seluruh karyawan PT Biro Klasifikasi Indonesia bagian SBU Energi.dalam penelitian ini adalah 115 karyawan dimana jumlah tersebut antara atasan (supervisor) dan karyawan level staf. Sehubungan dengan penelitian ini, maka dari jumlah jumlah keseluruhan karyawan pada bagian SBU Energi sebanyak 115 karyawan, yang terdiri dari 70 stafkaryawan dan 15 atasan (supervisor), 30 karyawan untuk uji coba di divisi lain. Kemudian karena dalam penelitian ini terdapat satu variabel tentang komitmen organisasi, sehingga yang dijadikan populasi dalam penelitian ini adalah seluruh staff karyawan bagian SBU Energi PT Biro Klasifikasi Indonesia (Persero) Jakarta Utara yang berjumlah 70 staf karyawan sebagai populasi.Teknik sampling jenuh (sensus) adalah sampel yang telah mewakili jumlah populasi,karena biasanya dilakukan jika populasi dianggap lebih kecil atau kurang dari 100.Jumlah sampel yang digunakan dalam penelitian ini sejumlah 70 karyawan yang terdiri dari staf karyawan bagian SBU Energi PT Biro Klasifikasi Indonesia (Persero) Jakarta Utara.

\section{HASIL DAN PEMBAHASAN}

\section{Uji Instrumen}

\section{Uji Validitas}

Uji validitas kuesioner disebar pada karyawan bagian yang berbeda namun memiliki kemiripan seperti karakteristik responden dan pekerjaan yang dilakukan. Dalam uji validitas ini peneliti menyebarkan ke 30 responden yang merupakan karyawan kantor pusat PT Biro Klasifikasi Indosesia (Persero).

Kriteria pengujian validitas jika $r_{\text {hitung }}>r_{\text {tabel }}(0,361)$, maka instrumen atau item pernyataan berkorelasi signifikan terhadap skor total (dinyatakan valid).Jika $r$ ${ }_{\text {hitung }}<\mathrm{r}_{\text {tabel }}(0,361)$, maka instrumen atau item pernyataan berkorelasi signifikas terhadap skor total (dinyatakan tidak valid).Hasil uji validitas dilihat pada tabel 3:

Tabel 3. Hasil Uji Validitas

\begin{tabular}{lccc}
\hline \multicolumn{1}{c}{ Variabel } & Item Sebelum Diuji & Item Tidak Valid & Item Valid \\
\hline Komitmen Organisasi & 10 & 0 & 10 \\
\hline Disiplin Kerja & 10 & 0 & 10 \\
\hline Lingkungan Kerja & 10 & 0 & 10 \\
\hline
\end{tabular}

Sumber : Data diolah peneliti, 2017 
Berdasarkan tabel 3, menunjukkan bahwa hasil uji validitas yang dilakukan pada variabel komitmen organisasi, disiplin kerja, dan lingkungan kerja tidak mempunyai item pernyataan yang tidak valid, karena $r_{\text {hitung tiap }}$ instrumennya lebih besar dari $r_{\text {tabel. }}$ Sehingga dapat disimpulkan bahwa seluruh butir pernyataan dalam variabel tersebut valid karena seluruh instrumen telah memenuhi syarat yaitu nilai $r_{\text {hitung }}>r_{\text {tabel }} 0.361$.

\section{Uji Reliabilitas}

Uji reliabilitas digunakan untuk mengetahui derajat ketepatan, ketelitian, atau keakuratan yang ditunjukkan oleh instrumen pengukuran. Kriteria pengujian reliabilitas adalah jika nilai cronbach's alpha> 0,6maka instrumen reliabel. Sebaliknya jika nilai cronbach's alpha $<0,6$ maka instrumen tidak reliabel.Hasil uji reliabilitas untuk masing-masing variabledapat dilihat pada tabel 4:

Tabel 4. Hasil Uji Reliabilitas

\begin{tabular}{lcc}
\hline \multicolumn{1}{c}{ Variabel } & Cronbach's Alpha & Keterangan \\
\hline Komitmen Organisasi $(\mathrm{Y})$ & 0.842 & Reliabel \\
\hline Disiplin Kerja $\left(\mathrm{X}_{1}\right)$ & 0.738 & Reliabel \\
\hline Lingkungan Kerja $\left(\mathrm{X}_{2}\right)$ & 0.742 & Reliabel \\
\hline
\end{tabular}

Sumber : Data diolah peneliti, 2017

Berdasarkan tabel 4, menunjukkan bahwa terlihat nilai Cronbach's Alpha> 0.6; untuk variabel kinerja karyawan, lingkungan kerja dan beban kerja secara berurutan adalah $0.842,0.738,0.742$. Instrumen dari ketiga variabel tersebut dinyatakan reliabel.

\section{Analisis Deskriptif}

Deskripsi data adalah hasil pengolahan data mentah variabel penelitian yang dimaksudkan untuk memberikan gambaran umum mengenai penyebaran dan distribusi data.Data yang didapatkan merupakan hasil penelitian melalui kuesioner yang disebarkan pada sampel 70 karyawan bagian SBU Energi PT Biro Klasifikasi Indonesia (Persero) Jakarta Utara.Kemudian untuk mengetahui bobot skor kriteria variabel dapat dilihat pada tabel 5:

Tabel 5. Bobot Skor Kriteria Variabel

\begin{tabular}{|c|c|c|c|c|}
\hline Variabel & Skor $>62,5 \%$ & $\begin{array}{c}\text { Kriteria } \\
\text { Pernyataan } \\
\text { Responden }\end{array}$ & Skor $<62,5 \%$ & $\begin{array}{c}\text { Kriteria } \\
\text { Pernyataan } \\
\text { Responden }\end{array}$ \\
\hline
\end{tabular}




\begin{tabular}{ccccc}
\hline Disiplin Kerja & Tinggi & SS/S & Rendah & STS/TS \\
\hline Lingkungan Kerja & Nyaman & STS/TS & Kurang Nyaman & SS/S \\
\hline Komitmen Organisasi & Tinggi & SS/S & Rendah & STS/TS \\
\hline
\end{tabular}

Sumber : Data diolah oleh peneliti, 2017

Hasil analisis deskriptif untuk masing-masing variabeldapat dilihat pada tabel 6 :

Tabel 6.Hasil Analisis Deskriptif

\begin{tabular}{lccc}
\hline & $\begin{array}{c}\text { Komitmen } \\
\text { Organisasi }\end{array}$ & Disiplin Kerja & Lingkungan Kerja \\
\hline Sangat Setuju & $27.0 \%$ & $26.0 \%$ & $9.9 \%$ \\
\hline Setuju & $22.0 \%$ & $22.0 \%$ & $29.2 \%$ \\
\hline Tidak Setuju & $23.0 \%$ & $30.0 \%$ & $42.1 \%$ \\
\hline Sangat Tidak Setuju & $28.0 \%$ & $22.0 \%$ & $18.8 \%$ \\
\hline
\end{tabular}

Sumber : Data diolah peneliti, 2017

Berdasarkan tabel 6, menunjukkan bahwa jawaban yang diberikan operator menggambarkan setiap variabel. Pada variabel komitmen organisasi jawaban yang dipilih operator didominasi oleh kategori sangat tidak setuju dengan persentase 51\%. Jika dibandingkan dengan bobot kriteria $51 \%<62,5 \%$. Dapat disimpulkan bahwa komitmen organisasi pada karyawan bagian SBU Energi PTBiro Klasifikasi Indonesia (Persero) Jakarta Utara termasuk ke dalam kategori rendah.dapat dilihat dari banyaknya jawaban responden yaitu sangat tidak setuju pada indikator nomor 3 dimensi komitmen afektif dengan pernyataan "saya merasa ingin melibatkan diri dalam upaya mencapai tujuan yang ditetapkan oleh perusahaan" artinya belum adanya kesadaran dalam diri karyawan untuk keterlibatan mencapai tujuan yang ditetapkan oleh perusahaandengan jawaban responden sangat tidak setuju. Selanjutnya, dapat dilihat pada indikator nomor 4 dimensi komitmen afektif dengan pernyataan "saya mau berusaha diatas batas normal untuk mensukseskan perusahaan" artinya sedikitnya karyawan yang memahami arti kerja keras dalam diri untuk mencapai kesuksesan perusahaan dengan jawaban responden sangat tidak setuju. Kemudian, dapat dilihat pada indikator nomor 8 dengan pernyataan "saya berusaha untuk melaksanakan semua tugas dan pekerjaan saya di perusahaan dengan penuh tanggung jawab" artinya masih rendahnya tanggung jawab dari dalam diri karyawan untuk melaksanakan semua tugas dan pekerjaan pada perusahaan dengan jawaban responden sangat tidak setuju. Jadi dapat disimpulkan bahwa komitmen organisasi dikategorikan rendah. 
Pada variabel disiplin kerja, jawaban yang dipilih responden didominasi oleh kategori tidak setuju dengan persentase sebesar 52\%. Jika dibandingkan dengan bobot kriteria 52\% $<62,5 \%$. Dapat disimpulkan bahwa disiplin kerjapada karyawan pada karyawan bagian SBU Energi PTBiro Klasifikasi Indonesia (Persero) Jakarta Utara termasuk ke dalam kategori rendah.Adapun beberapa penyebab disiplin kerja rendah, dapat dilihat dari banyaknya jawaban responden yaitu tidak setuju pada indikator nomor 1 dimensi kehadiran dengan pernyataan "saya datang tepat waktu dalam bekerja" artinya masih sangat rendah tingkat kehadiran karyawan untuk datang tepat waktu serta rendahnya kesadaran dalam diri karyawan.Selanjutnya, dapat dilihat pada indikator nomor 7 dimensi ketaatan standar kerja dengan pernyataan "saya menggunakan peralatan kantor dengan efektif dan efisien" artinya karyawan belum dapat memaksimalkan penggunaan peralatan atau fasilitas kantor. Kemudian, dapat dilihat pada indikator nomor 10 dimensi etika kerja dengan pernyataan "saya menghargai saat karyawan lain memberikan pendapat dalam bekerja" artinya karyawan belum mampu menjalin keharmonisan dalam bekerja sehingga dapat dikatakan rendahnya etika dalam bekerja. Jadi dapat disimpulkan bahwa disiplin kerja dikategorikan rendah.

Sedangkan pada variabel lingkungan kerja, jawaban yang dipilih responden didominasi oleh kategori setuju dengan persentase sebesar 60,9\%. Jika dibandingkan dengan bobot kriteria variabel 60,9\% $<62,5 \%$. Dapat disimpulkan bahwa lingkungan kerjakaryawan bagian SBU Energi PTBiro Klasifikasi Indonesia (Persero) Jakarta Utara termasuk ke dalam kategori kurang nyaman.Adapun beberapa penyebab lingkungan kerja kurang nyaman, dapat dilihat dari banyaknya jawaban responden yaitu tidak setuju pada indikator nomor 3 dimensi lingkungan kerja fisik dengan pernyataan "saya merasa aman dalam bekerja karena karena adanya jaminan keamanan lingkungan yang diberikan perusahaan kepada karyawan" artinya masih sangat rendah tingkat keamanan lingkungan yang diberikan perusahaan karyawan dalam melaksanakan tugas atau pekerjaan.Selanjutnya, dapat dilihat pada indikator nomor 5 dimensi lingkungan kerja fisik dengan pernyataan "sirkulasi udara di tempat saya bekerja membuat saya dapat bernafas dengan oksigen yang cukup" artinya karyawan masih kurang 
nyaman dengan sirkulasi udara yang tersedia di kantor karna polusi udara yang disebabkan oleh konstruksi bagunan yang sedang dalam tahap renovasi menggunakan peralatan kantor. Kemudian, dapat dilihat pada indikator nomor 8 dimensi lingkungan kerjanon fisik dengan pernyataan "saya merasakan komunikasi yang baik antara saya dengan atasan saya di perusahaan sehingga dapat memperlancar pekerjaan" artinya hubungan antara atasan dengan bawahan belum terciptanya suasana yang dekmoratis karna hanya mendengarkan perintah dari atasan saja dan dalam membuat keputusan secara mutlak atas perintah dari atasan sedangkan bawahan hanya bersifat mengikuti keputusan yang sudah dibuat. Jadi dapat disimpulkan bahwa lingkungan kerja dikategorikan kurang nyaman.

\section{Uji Asumsi Klasik \\ Uji Normalitas}

Uji normalitas menurut Umar (2009:181) dilakukan untuk mengetahui apakah setiap variabel berdistribusi normal atau tidak.Uji ini menggunakan Kolmogrov-Smirnov dengan signifikansi $>0.05$. Hasil uji normalitas dapat dilihat pada tabel 7:

Tabel 7. Hasil Uji Normalitas

One-Sample Kolmogorov-Smirnov Test

\begin{tabular}{llrrr}
\hline & & $\begin{array}{c}\text { Komitmen } \\
\text { Organisasi }\end{array}$ & Disiplin Kerja & $\begin{array}{c}\text { Lingkungan } \\
\text { Kerja }\end{array}$ \\
\hline $\mathrm{N}$ & & 70 & 70 & 70 \\
Normal Parameters & Mean & 29,6857 & 32,2143 & 27,0000 \\
& Std. Deviation & 4,92124 & 3,94858 & 5,48516 \\
Most Extreme Differences & Absolute &, 067 &, 074 &, 087 \\
& Positive &, 065 &, 070 &, 049 \\
Kolmogorov-Smirnov Z & Negative &,- 067 &,- 074 &,- 087 \\
Asymp. Sig. (2-tailed) &, 067 &, 074 &, 087 \\
\hline a. Test distribution is Normal. &, 200 &, 200 &, 200 \\
b. Calculated from data. & & & \\
Sumber : Perhitungan SPSS 21, 2017 & & &
\end{tabular}

Berdasarkan tabel 7, menunjukkan bahwa hasil uji normalitas dengan SPSS dapat dilihat bahwa dengan taraf uji sebesar $5 \%(\alpha=0,05)$ semua variabel memiliki Pvalueuntuk komitmen organisasi0.200, disiplin kerja0.200,dan lingkungan kerja 0.200(sig.) sehingga dapat disimpulkan bahwa semua variabel berdistribusi normal sehingga memenuhi syarat dilakukan metode statistik parametrik analisis regresi linear berganda.

\section{Uji Linearitas}


Menurut Juliansyah (2012:178) uji linearuntuk mengetahui apakah pengaruh suatu variabel terhadap variabel lainnya dan untuk mengetahui tingkat keeratan hubungan yang linear antara dua variabel atau tidak.Pengujian ini menggunakan test of linearity dengan taraf signifikansi kurang dari 0.05 .

Uji liniearitas dilakukan dilakukan dengan mencari persamaan garis regresi variabel disiplin kerja $\left(\mathrm{X}_{1}\right)$ dan lingkungan kerja $\left(\mathrm{X}_{2}\right)$ terhadap komitmen organisasi (Y). Hasil uji linearitas dapat dilihat pada tabel 8:

Tabel 8. Hasil Uji Linearitas Antara Variabel Disiplin Kerja dengan Variabel Komitmen Organisasi ANOVA Table

\begin{tabular}{|c|c|c|c|c|c|c|}
\hline & & Sum of Squares & Df & $\begin{array}{l}\text { Mean } \\
\text { Square }\end{array}$ & $\mathrm{F}$ & Sig. \\
\hline \multirow{5}{*}{$\begin{array}{l}\text { Komitmen Organisası } \\
\text { * Disiplin Kerja }\end{array}$} & Between (Combined) & 827.180 & 16 & 51.699 & 3.247 & .001 \\
\hline & Linearity & 585.602 & 1 & 585.602 & 36.778 & .000 \\
\hline & $\begin{array}{l}\text { Deviation } \\
\text { from Linearity }\end{array}$ & 241.578 & 15 & 16.105 & 1.011 & .458 \\
\hline & Within Groups & 843.906 & 53 & 15.923 & & \\
\hline & Total & 1671.086 & 69 & & & \\
\hline
\end{tabular}

Sumber : Perhitungan SPSS 21, 2017

Berdasarkan tabel 8, menunjukkan bahwa hasil uji linieritas antara variabel disiplin kerja dengan variabel komitmen organisasi pada tabel 7 diatas, diketahui bahwa nilai signifikansi linearity sebesar 0.000. Artinya, nilai signifikansi tersebut kurang dari 0,05 sehingga dapat disimpulkan bahwa antara kedua variabel tersebut terdapat hubungan yang linear.

Tabel 9. Hasil Uji Linearitas Antara Variabel Lingkungan Kerja dengan Variabel Komitmen Organisasi ANOVA Table

\begin{tabular}{|c|c|c|c|c|c|c|}
\hline & & Sum of Squares & df & $\begin{array}{l}\text { Mean } \\
\text { Square }\end{array}$ & $\mathrm{F}$ & Sig. \\
\hline \multirow{5}{*}{$\begin{array}{l}\text { Komitmen } \\
\text { Organisasi* } \\
\text { Lingkungan Kerja }\end{array}$} & Between (Combined) & 1115.157 & 21 & 53.103 & 4.585 & .000 \\
\hline & Groups Linearity & 501.156 & 1 & 501.156 & 43.271 & .000 \\
\hline & $\begin{array}{l}\text { Deviation from } \\
\text { Linearity }\end{array}$ & 614.001 & 20 & 30.700 & 1.251 & .103 \\
\hline & Within Groups & 555.929 & 48 & 11.582 & & \\
\hline & Total & 1671.086 & 69 & & & \\
\hline
\end{tabular}

Sumber : Perhitungan SPSS 21, 2017

Berdasarkan tabel 9, menunjukkan bahwa hasil uji linieritas antara variabel lingkungan kerja dengan variabel komitmen organisasi pada tabel 9 diatas, diketahui bahwa nilai signifikansi linearity sebesar 0.000. Artinya, nilai signifikansi tersebut kurang dari 0,05 sehingga dapat disimpulkan bahwa antara kedua variabel tersebut terdapat hubungan yang linear. 


\section{Uji Multikolinearitas}

Menurut Qudratullah (2013:179) uji multikolinearitasuntuk mengetahui apakah pada model regresi ditemukan adanya korelasi antar variabel independen.Hubungan multikolinearitas dapat dideteksi dengan menggunakan VIF (Variance Inflation Factor).VIF adalah salah satu estimasi berapa besar multikolinearitas meningkatkan varian pada suatu koefisien estimasi sebuah variabel penjelas. Hasil uji multikolinearitas dapat dilihat pada tabel 10:

Tabel 10. Hasil Uji Multikolinearitas

\begin{tabular}{|c|c|c|c|}
\hline \multicolumn{4}{|c|}{ Coefficients $^{a}$} \\
\hline & \multirow{2}{*}{ Model } & \multicolumn{2}{|c|}{ Collinearity Statistics } \\
\hline & & Tolerance & VIF \\
\hline \multirow{3}{*}{1} & (Constant) & & \\
\hline & Disiplin Kerja & ,889 & 1,125 \\
\hline & Lingkungan Kerja & ,889 & 1,125 \\
\hline
\end{tabular}

Berdasarkan tabel 10, menunjukkan bahwa hasil uji multikolinearitas dengan menggunakan statistik pengolahan data, diketahui angka VIF untuk disiplin kerja sebesar 1.125 dan lingkungan kerjasebesar 1.125.Nilai VIF dari seluruh variabel bebas adalah kurang dari 10 atau mendekati 1, maka di antara kedua variabel bebas tersebut tidak ditemukan adanya masalah multikolinearitas.

\section{Uji Heteroskedastisitas}

Menurut Priyatno (2010:67) uji heteroskedastisitas adalah keadaan dimana terjadinya ketidaksamaan varian dari residual pada model regresi.Model regresi yang baik mensyaratkan tidak ada masalah heteroskedastisitas. Metode yang digunakan dalam penelitian ini adalah metode uji Spearman's Rho, yaitu mengkorelasikan nilai residual (unstandardized residual) dengan masing-masing variabel independen. Jika signifikansi kurang dari 0,05 , maka terjadi masalah heteroskedastisitas. Hasil uji heteroskedastisitas dapat dilihat pada tabel 11:

Tabel 11. Hasil Uji Heterokedastisitas Correlations

\begin{tabular}{|c|c|c|c|c|c|}
\hline & & & $\begin{array}{c}\text { Unstandardized } \\
\text { Residual }\end{array}$ & $\begin{array}{l}\text { Disiplin } \\
\text { Kerja }\end{array}$ & $\begin{array}{c}\text { Lingkungan } \\
\text { Kerja }\end{array}$ \\
\hline \multirow[t]{2}{*}{$\begin{array}{l}\text { Spearman's } \\
\text { rho }\end{array}$} & \multirow[t]{2}{*}{$\begin{array}{l}\text { Unstandardized } \\
\text { Residual }\end{array}$} & $\begin{array}{l}\text { Correlation } \\
\text { Coefficient }\end{array}$ & 1.000 & .025 & .049 \\
\hline & & Sig. (2-tailed) & . & .837 & .684 \\
\hline
\end{tabular}




\begin{tabular}{llrrr}
\multirow{2}{*}{ Disiplin Kerja } & N & 70 & 70 & 70 \\
& Correlation & .025 & 1.000 & .362 \\
& Coefficient & .837 & & .002 \\
& Sig. (2-tailed) & 70 & 70 & 70 \\
& N & .049 & .362 & 1.000 \\
Lingkungan Kerja & Correlation & .684 & .002 &. \\
& Coefficient & 70 & 70 & 70 \\
& Sig. (2-tailed) & N & & \\
& &
\end{tabular}

Sumber : Perhitungan SPSS 21, 2017

Berdasarkan tabel 11, menunjukkan bahwa korelasi antara disiplin kerja dengan unstandardizedresidual menghasilkan nilai signifikasi 0,837; korelasi antara beban kerja dengan unstandardized residual menghasilkan nilai 0.684. Jadi, dapat disimpulkan bahwa pada model regresi tidak ditemukan adanya masalah heterokedastisitas hal ini karena nilai signifikansi korelasi lebih besar dari 0.05 .

\section{Uji Hipotesis}

\section{Hasil Uji t}

\begin{tabular}{|c|c|c|c|c|c|c|}
\hline \multicolumn{7}{|c|}{$\begin{array}{c}\text { Tabel 12. Hasil Uji t } \\
\text { Coefficients }^{\mathrm{a}}\end{array}$} \\
\hline \multirow[b]{2}{*}{ Model } & & \multicolumn{2}{|c|}{ Unstandardized Coefficients } & $\begin{array}{l}\text { Standardized } \\
\text { Coefficients }\end{array}$ & \multirow[b]{2}{*}{$\mathrm{T}$} & \multirow[b]{2}{*}{ Sig. } \\
\hline & & $\mathrm{B}$ & Std. Error & Beta & & \\
\hline \multirow[t]{3}{*}{1} & (Constant) & 1,644 & 3,674 & & ,447 &, 656 \\
\hline & Disiplin Kerja &, 574 &, 115 & ,461 & 4,971 &, 000 \\
\hline & Lingkungan Kerja & 354 & 083 & ,394 & 4,253 &, 000 \\
\hline
\end{tabular}

a. Dependent Variable: KomitmenOrganisasi

Sumber : Perhitungan SPSS 21, 2017

\section{Hipotesis $1\left(\mathbf{H}_{1}\right)$}

Ho : Disiplin kerja tidak berpengaruh terhadap komitmen organisasi karyawan PTBiro Klasifikasi Indonesia (Persero) JakartaUtara.

$\mathrm{Ha}$ : Disiplin kerja berpengaruh terhadapkomitmen organisasi karyawan PTBiroKlasifikasi Indonesia (Persero) Jakarta Utara.

Berdasarkan tabel 12, menunjukkan bahwa nilai $t_{\text {hitung dibandingkan }}$ dengan nilai $t_{\text {tabel }}$ yang dicari pada $\alpha=5 \%: 2=2,5 \%$ (uji 2 sisi) dengan derajat kebebasan(df) n-k-1 atau 70-2-1, dimana $n$ adalah jumlah sampel dan $\mathrm{k}$ adalah jumlah variabel bebas. Berdasarkan perhitungan tersebut, didapat $t_{\text {tabel }}$ sebesar 1,667 dengan demikian $t_{\text {hitung }}(4,971)>t_{\text {tabel }}(1,667)$ serta nilai signifikansi $0,000<$ 0.05.Kesimpulan yang dapat diambil dari hipotesis 1 adalah $\mathrm{H}_{0}$ ditolak dan 
$\mathrm{H}_{\mathrm{a}}$ diterima.Dengan demikian disiplin kerja memiliki pengaruh positif dan signifikan terhadap komitmen organisasi.

Hal tersebut di dukung oleh penelitian yang telah dilakukan Anwar Prabu Mangkunegara (2015), Yayuk Liana dan Rina Irawati (2014), Gerry J. Jr Wowor (2013), Endang Setyaningdyah (2013), Poltak Palmer Marjohan (2013). Berdasarkan penelitian tersebut disiplin kerja terbukti memiliki pengaruh yang positif dan signifikan terhadap komitmen organisasi pada karyawan bagian SBU Energi PT Biro Klasifikasi Indonesia (Persero) Jakarta Utara. Hal tersebut didukung oleh Yayuk Liana dan Rina (2014:1) menyatakan bahwa disiplin kerja yang tinggi pada karyawan akan berdampak pada komitmen karyawan dalam organisasi.Dengan adanya disiplin kerja yang dimiliki oleh karyawan, artinya mereka dapat bekerja dengan baik serta berusaha selalu mematuhi semua aturanaturan yang telah disepakati.

\section{Hipotesis $2\left(\mathbf{H}_{2}\right)$}

Ho : Lingkungan kerja tidak berpengaruh terhadap komitmen organisasi karyawan PTBiro Klasifikasi Indonesia (Persero) Jakarta Utara.

Ha : Lingkungan kerja berpengaruh terhadap komitmen organisasi karyawan PTBiro Klasifikasi Indonesia (Persero) Jakarta Utara.

Selanjutnya, tabel 12 juga menunjukkan $t_{\text {hitung }}$ untuk variabel lingkungan kerja sebesar 4,253. Hal tersebut menunjukkan bahwa $t_{\text {hitung }}(4,253)>t_{\text {tabel }}(1,667)$ dan nilai signifikansi $0,000<0.05$.Kesimpulan yang dapat diambil dari hipotesis 2, $\mathrm{H}_{0}$ ditolak dan $\mathrm{H}_{\mathrm{a}}$ diterima.Dapat disimpulkan bahwa lingkungan kerja berpengaruh positif dan signifikan terhadap komitmen organisasi.

Hal tersebut didukung olehpenelitian yang telah dilakukan Devi (2013), Nina (2014), Rahmita (2015) dan Jalal (2016).Berdasarkan penelitian tersebut lingkungan kerja terbukti memiliki pengaruh yang positif dan signifikan terhadap komitmen organisasi PT Biro Klasifikasi Indonesia (Persero) Jakarta Utara.Hal tersebut didukung olehNitiseminto dalam Kurniasari (2013:11) menyatakan bahwa lingkungan kerja merupakan segala sesuatu yang ada di sekitar para pekerja dan yang dapat mempengaruhi dirinya dalam menjalankan tugas-tugas yang dibebankan.Lingkungan kerja yang nyaman akan mampu meningkatkan 
komitmen organisasi karyawan. Sebaliknya apabila lingkungan kerja yang kurang nyaman akan mengakibatkan turunnya komitmen organisasi karyawan.

\section{Hasil Uji F}

Tabel 13. Hasil Uji F ANOVA $^{a}$

\begin{tabular}{llrrrrr}
\hline Model & & Sum of Squares & Df & Mean Square & \multicolumn{1}{c}{ F } & Sig. \\
\hline 1 & Regression & 816,359 & 2 & 408,180 & 31,996 &, $000^{\mathrm{b}}$ \\
& Residual & 854,726 & 67 & 12,757 & & \\
& Total & 1671,086 & 69 & & & \\
\hline
\end{tabular}

a. Dependent Variable: Komitmen Organisasi

b. Predictors: (Constant), Disiplin Kerja, Lingkungan Kerja Sumber : Perhitungan SPSS 21, 2017

\section{Hipotesis $3\left(\mathbf{H}_{3}\right)$}

Ho : Disiplin Kerja dan Lingkungan Kerja tidak dapat memprediksi kenaikan Komitmen Organisasi karyawan PT Biro Klasifikasi Indonesia (Persero) Jakarta Utara.

Ha : Disiplin Kerja dan Lingkungan Kerja dapat memprediksi kenaikan Komitmen Organisasi karyawan PT Biro Klasifikasi Indonesis (Persero) Jakarta Utara.

Berdasarkan tabel 13, menunjukkan bahwanilai $\mathrm{F}_{\text {hitungdibandingkan dengan }}$ nilai $\mathrm{F}_{\text {tabel, }}$ yang dicari dengan $\alpha=5 \%$, dengan df1 $=\mathrm{k}-1$ atau $3-1=2$ dan df $2=$ $(\mathrm{n}-\mathrm{k}-1)$ atau 70-2-1 = $67\left(\mathrm{k}=\right.$ jumlah variabel). Menghasilkan $\mathrm{F}_{\text {tabel }}$ sebesar 3,13.

Dari hasil perhitungan diatas maka $F_{\text {hitung }}(31,996)>F_{\text {tabel }}(3,13)$ dengan signifikansi $0,000<0,05$. Dengan hal ini, maka $\mathrm{H}_{0}$ ditolak dan $\mathrm{H}_{\mathrm{a}}$ diterima dapat disimpulkan bahwa variabel disiplin kerja dan lingkungan kerja dapat memprediksi komitmen organisasi karyawan.

\section{Hasil Persamaan Regresi Linear Berganda}

Menurut Sugiyono (2009:250) analisis regresi linear berganda adalah hubungan secara linear antara dua atau lebih variabel independen dengan variabel dependen. Model regresi linear berganda adalah sebagai berikut: 


$$
\mathbf{Y}=\mathbf{a}+\mathbf{b}_{1} \mathbf{X}_{1}+\mathbf{b}_{2} \mathbf{X}_{2}+\mathbf{e}
$$

Keterangan:

$\mathrm{Y} \quad=$ Variabel Terikat (Komitmen Organisasi)

$\mathrm{a}, \mathrm{b}_{1}, \mathrm{~b}_{2}=$ Parameter

$\mathrm{X}_{1}=$ Variabel Bebas Pertama (Disiplin Kerja)

$\mathrm{X}_{2} \quad=$ Variabel Bebas Kedua (Lingkungan Kerja)

Untuk persamaan regresi linearberganda untuk hipotesis ketiga seperti berikut ini:

$$
\mathrm{Y}^{\prime}=1,644+0,574 \mathrm{X}_{1}+0,354 \mathrm{X}_{2}
$$

Parameter pada model persamaan tersebut sebesar 1,644.Dengan demikian, jika variabel disiplin kerja dan lingkungan kerjabernilai 0 , maka variabel komitmen organisasi karyawan bernilai 1,644.

Koefisien regresi variabel disiplin kerjasebesar 0,574 bertanda positif.artinya, jika variabel disiplin kerja ditingkatkan sebesar 0,574 makavariabel lingkungan kerja akan mengalami kenaikan sebesar 0,574 dan disiplin kerja berpengaruh positif terhadap komitmen organisasi karyawan.Kemudian koefisien regresi variabel lingkungan kerjasebesar 0,354 bertanda positif. Artinya jika variabel lingkungan kerja ditingkatkan sebesar 0,354 maka variabel komitmen organisasi akan mengalami kenaikan sebesar 0,354 dan lingkungan kerja berpengaruh positif terhadap komitmen organisasi karyawan.

Koefisien pada kedua variabel bernilai positif dan positif, artinya terjadi pengaruh positif variabel disiplin kerja dan positif variabel lingkungan kerja terhadap komitmen organisasi karyawan.

\section{Analisis Koefisien Determinasi $\left(\mathbf{R}^{2}\right)$}

Menurut Sanusi (2017:136) analisis koefisien determinasi $\left(\mathrm{R}^{2}\right)$ menjelaskan tentang proporsi variasi dalam variabel terikat (Y) yang dijelaskan oleh variabel bebas (lebih dari satu variabel) secara bersama-sama.Hasil uji koefisien determinasi $\left(\mathrm{R}^{2}\right)$ dapat dilihat pada tabel 14 :

Tabel 14. Hasil Analisis Determinasi Model Summary

\begin{tabular}{lrrrr}
\hline \multicolumn{4}{c}{ Model Summary } \\
\hline Model & R & R Square & Adjusted R Square & $\begin{array}{c}\text { Std. Error of the } \\
\text { Estimate }\end{array}$ \\
\hline 1 & $.699^{\mathrm{a}}$ & .489 & .473 & 3.57171 \\
\hline
\end{tabular}

a. Predictors: (Constant), Disiplin Kerja, Lingkungan Kerja Sumber : Perhitungan SPSS 21, 2017 
Berdasarkan tabel 14, menunjukkan bahwa nilai $\mathrm{R}^{2}$ sebesar 0,489 atau (48,9\%). Hal ini menunjukkan bahwa 48,9\% komitmen organisasi dijelaskan oleh faktor disiplin kerja dan lingkungan kerja sedangkan sisanya sebesar 51,1\% dijelaskan oleh variabel lain yang tidak diteliti.

\section{KESIMPULAN DAN SARAN Kesimpulan}

Berdasarkan hasil penelitian mengenai "Pengaruh Disiplin Kerja dan Lingkungan Kerja Terhadap Komitmen Organisasi Pada Karyawan Bagian SBU Energi PT Biro Klasifikasi Indonesia (Persero) Jakarta Utara”, menghasilkan kesimpulan sebagai berikut:

1. Disiplin kerja memiliki pengaruh positif dan signifikan terhadap komitmen organisasi karyawan pada bagian SBU Energi PTBiro Klasifikasi Indonesia (Persero) Jakarta Utara.

2. Lingkungan kerja memiliki pengaruh positif dan signifikan terhadap komitmenorganisasi karyawan pada bagian SBU Energi PTBiro Klasifikasi Indonesia (Persero) Jakarta Utara.

3. Disiplin kerja dan lingkungan kerja secara bersama-sama atau simultan berpengaruh terhadap komitmen organisasi karyawan pada bagian SBU Energi PTBiro Klasifikasi Indonesia (Persero) Jakarta Utara.

\section{Saran}

Berdasarkan kesimpulan di atas, beberapa saran yang diajukan dalam penelitian adalah sebagai berikut:

1. Perusahaan disarankan untuk memperbaiki, menjaga dan meningkatkan lingkungan kerja bagi para karyawan agar lebih terdorong untuk meningkatkan komitmen organisasi karyawan. Perusahaan disarankan agar memperhatikan lingkungan kerja fisik dengan cara memperbaiki sistem sirkulasi udara dengan memberikan ventilasi yang sesuai dan memperluas ruang kerja karyawan agar karyawan leluasa dalam melakukan aktivitasnya. Selain itu, perusahaan juga harus memperhatikan lingkungan kerja non fisik dengan cara menciptakan hubungan yang harmonis dan tumbuhnya rasa 
solidaritas sesama rekan kerja maupun atasan dengan bawahan agar dapat membangun kerjasama yang baik dalam menyelesaikan pekerjaan.

2. Perusahaan disarankan untuk memperhatikan partisipasi semua karyawan baik dari atasan dan bawahan di lingkungan kantor bagian SBU Energi PT Biro Klasifikasi Indonesia (Persero) Jakarta Utara untuk menegakkan disiplin kerja, tanggung jawab, serta pemahaman yang baik mengenai disiplin. Kemudian, memperinci kembali disiplin kerja yang ingin diterapkan sehingga karyawan lebih paham dan tidak melakukan pelanggaran lagi.

3. Berdasarkan penelitian ini, untuk komitmen organisasi karyawan pada bagian SBU Energi PTBiro Klasifikasi Indonesia (Persero) Jakarta Utara diperlukan kepercayaan yang kuat memberikan untuk kontribusi yang terbaik dan mempertahankan keanggotaannya dalam perusahaan.

\section{DAFTAR PUSTAKA}

\section{Buku}

Greenberg, Jerald. dan Robert A Baron.(2009). Behavior in Organizations.New Jersey: Pearson Prentice Hall

Hasibuan, Malayu.(2009).Manajemen Sumber Daya Manusia. Jakarta: PT Bumi Aksara.

Iskandar.(2013). Metodologi Penelitian Pendidikan dan Sosial. Jakarta: Referensi.

Kaswan.(2012). Manajemen Sumber Daya Manusia. Yogyakarta: Graha Ilmu.

Luthans, Fred.(2011). Organizational Behavior, $12^{\text {th }}$ ed.New York: McGraw-Hill Irwin.

Mangkunegara, Anwar Prabu.(2010). Perilaku dan Disiplin kerja Organisasi.Bandung: RefikaAditama,

Nitisemito, Alex. (2009). Manajemen Personalia Edisi Revisi. Jakarta: Ghalia.

Priyatno, Duwi.(2010). Teknik Mudah dan Cepat Melakukan Analisis Data Penelitiandengan SPSS dan Tanya Jawab Ujian Pendadaran. Yogyakarta: Gava Media.

Rivai, Veithzal dan Ella Jauvani Sagala.(2009). Manajemen Sumber Daya Manusia untukPerusahaan dari Teori ke Praktik. Jakarta: Rajagrafindo Persada. 
Robbins, Stephen P dan Timothy A. Judge.(2009). Organizational Behavior. New Jersey: Person Education, Inc.

Sedarmayanti.(2011). Sumber Daya Manusia dan Produktivitas Kerja.Bandung: Mandar Maju.

Sopiah.(2010). Perilaku Organisasional.Yogyakarta: ANDI.

Sugiyono.(2010). Metodologi Penelitian Bisnis.Bandung: Alfabeta.

\section{Jurnal}

Hanaysha,Jalal.(2016). Testing The Effects of Employee Engagement, Work Environment, and Organizational Learning on Organizational Commitment. Journal Senior Lecturer at Faculty of Business and Management, DRBHicom University of Automotive Malaysia.

Kurniasari, Devi. (2013). Pengaruh Lingkungan Kerja dan Iklim Organisasi Terhadap Komitmen Organisasi Melalui Kepuasan Kerja Karyawan Pada Dinas Pasar Unit Pasar Tanjung Kabupaten Jember.Jurnal Manajemen Universitas Darma Persada Jakarta.

Liana, Yayuk dan Rina.(2014). Peran Motivasi, Disiplin Kerja, Terhadap Komitmen Karyawan Dan Kinerja Karyawan Pada Perusahaan Air Minum di Malang Raya.Jurnal Manajemen dan Akuntansi.

Maharani, Devi Rahmita.(2015). Pengaruh Kualitas Kehidupan Kerja Dan Lingkungan Kerja Terhadap Komitmen Organisasi Karyawan Studi Pada Divisi Peralatan Industri Agro PT. Barata Indonesia (Persero).Jurnal Ekonomi Universitas Negeri Surabaya.

Mangkunegara, Anwar Prabu dan Tinton Rumbungan Octorend.(2015). Effect of Work Discipline, Work Motivation and Job Satisfaction on Employee Organizational Commitment in the Company (Case Study inPT. Dada Indonesia).Journal of Management.

Wowor, Gerry J. Jr. et.al.(2011).Pengaruh Lingkungan Kerja dan Disiplin Terhadap Komitmen Organisasional Pada Karyawan Media Cahaya Pagi. 